\title{
Review of John Mizzoni's Evolution and the Foundations of Ethics. Lanham: Lexington Books, 2017, 272 pp.
}

Vaios Koliofotis

Erasmus University Rotterdam

Among the more noticeable new developments in economics is the flourishing stream of studies that consider the interplay of cultural, biological and ethical factors in the explanation of human behavior (e.g. Hodgson, 2013). Work in evolutionary biology informs economics and points to the need to investigate the exciting philosophical issues that surround collaboration between disciplines. Key features of research methods, concepts and strategies employed by evolution-minded economists can spark novel debates and more fine-grained work in philosophy of economics.

One of the most compelling tasks is to summarize extensive multifaceted knowledge in a form that would allow researchers to understand and evaluate the contribution of evolutionary thinking in modern ethics and meta-ethics. Although philosophers of economics have contributed to debates concerning both the philosophy of biology (e.g. Vromen 2017) and the foundations of ethics (e.g. Broome, 1999), none has set out the challenging but important task to survey the application of evolutionary reasoning to all the major theories that have been developed by contemporary moral philosophers.

The book Evolution and the Foundation of Ethics by philosopher John Mizzoni is an ambitious attempt to provide a broad-based discussion of the interface between moral philosophy and evolutionary theory. The book grew out of Mizzoni's earlier philosophical work on ethics and meta-ethics (e.g. Mizzoni, 2005; 2010) and conveys the complexity of issues involved in the attempt to naturalize ethics via evolutionary biology.

After a short introduction in which Mizzoni summarizes the evolutionary models of Darwin, Dawkins, Gould, and Haught, the eleven main chapters examine the implications of these models for normative and meta-ethical theories. Mizzoni attempts to answer four interrelated 
questions: a) if we understand human psychology and behaviour as the outcome of biological evolution, how do standard ethical and metaethical theories fit in? b) do ethical concepts and principles make sense when placed in an evolutionary framework? c) in light of biological evolution, do we need to abandon traditional ethics? d) do we need to create new evolutionary ethics?

The book is organized into two parts. The first part (Chapters 2-5) presents four meta-ethical theories that explain the general nature, status, and origins of ethics. After presenting their main elements, Mizzoni analyzes the implications of evolutionary models for errortheory (Chapter 2), expressivism (Chapter 3), moral relativism (Chapter 4) and moral realism (Chapter 5).

The first part of the book provides to the field of philosophy of economics a systematic review and synthesis of research being done in metaethics. Mizzoni makes a strong case for the importance of evolutionary theory in the explanation of the general nature and origins of ethics. For example, a naturalistic evolutionary perspective might help explain why commonsense morality is an error (e.g. Ruse, 1998). It also provides support to the expressivists' view of moral progress and their emphasis on the importance of emotion in moral statements and judgements (e.g. Blackburn, 1996). However, Haught's model of theistic evolution is clearly anti-expressivist and ethical objectivity is not seen as an error. In the case of metaethical relativism, Wong's moderate approach that acknowledges universal constraints on morality can find potential support from both naturalistic and theistic models of evolution (Wong, 2006). The final chapter of the first part of the book outlines the main elements of moral realism (e.g. Shafer-Landau, 2003; Railton, 2003) and Mizzoni argues that it is possible to integrate moral realism with naturalistic and theistic evolutionary approaches.

Philosophers of economics interested in normative ethics will find the second part of Mizzoni's book (Chapters 6-11) worthy of their attention. Although normative economics has traditionally taken a consequentialist approach, the study of normative ethics is a very broad enterprise and philosophers of economics inevitably come across virtue ethics (e.g. Wells and Graafland, 2012; Bruno and Sugden, 2013, social contract theory (e.g. Binmore 1994; 1998) and deontological ethics (White, 2011). Each chapter presents a normative ethical theory and investigates whether it can be conjoined with an evolutionary perspective on human origins. Mizzoni examines virtue ethics (Chapter 
6), natural law ethics (Chapter 7), social contract ethics (Chapter 8), deontological ethics (Chapter 9), utilitarianism (Chapter 10) and care ethics (Chapter 11).

After a short presentation of Aristotelian and neo-Aristotelian virtue ethics (Nussbaum, 1988), Mizzoni draws on recent theorists like Churchland $(1996,1998)$ to argue that neo-Aristotelian virtue ethics does not depend on Aristotle's cosmology. From a close examination of virtue ethics from the perspective of naturalistic and theistic theories of evolution, it is clear that that virtue ethics fits well into evolutionary frameworks. Another normative ethical theory whose roots go back to Ancient Greece is natural law ethics. Mizzoni examines Aquinas version of natural law ethics and reviews how contemporary researchers like Craig Boyd (2007) and Larry Arnhart (1998) defend the view that natural law ethics are in accord with Darwin's account and Dawkins' model of evolution.

The chapter on social contract ethics lays out the main points of Thomas Hobbes' view of human nature before examining how evolutionary game theory can deflect some common objections to social contract theory. Mizzoni rightly observes that Skyrms (1996), Axelrod (1984) and de Waal (1996) use concepts and reasoning that are part and parcel of contractarian ethical theory. A less popular theory among evolutionary theorists is deontological ethics. For example, Dawkins and Gould have explicitly argued against Kantian ethics. According to Mizzoni the key question is whether evolutionary theory undermines deontological ethics. After examining alternative naturalistic models of evolution he argues that key elements of deontological ethics like autonomy make sense when placed in an evolutionary context.

Less controversial from an evolutionary perspective are utilitarian ethics. After presenting the main utilitarian principles and concepts, Mizzoni examines what contemporary thinkers like Ruse (1998) and Singer $(1981,1999)$ have argued about the relation between evolution and utilitarian ethics. From the perspective of naturalistic evolutionary theories, Darwin's views do not contradict utilitarianism while Dawkins gene-centered approach, Gould's model of evolution and Haught's theistic evolution are consistent with utilitarian ethics. The second part of the book concludes with care ethics, a more recent normative theory that puts emphasis on human needs and the quality of personal relationships (e.g. Held, 2006; Noddings, 2010). Care ethics looks at normative ethics from the perspective of female experience and 
suggests that the maternal disposition to care about an infant's survival is one of the sources of human morality. Care ethicists do not dwell deep into evolutionary theory and Mizzoni's analysis of particular evolutionary models reveals that they support key elements of this normative theory.

Mizzoni concludes that the main normative and metaethical theories are compatible with evolution and the fundamental notions of these theories fit into an evolutionary perspective. In light of the four evolutionary models, there is no need to abandon traditional ethical approaches while none of the normative and metaethical theories suggest that there is a need to build a new evolutionary ethic.

One criticism is that the comprehensiveness of the book often prevents the discussion from going into sufficient depth. This is a standard limitation of any book that attempts to address a broad range of theories and topics. To give an example, the analysis of error theory is thorough and Mizzoni offers a wealth of challenging and thoughtprovoking ideas that immensely enhance the quality of the book. In contrast, contemporary debates in meta-ethics revolve around the so called "evolutionary debunking arguments" against moral realism: evolutionary explanations of moral beliefs (or faculties) appear to undermine the realist claim of the possibility of moral knowledge. In response, Mizzoni develops possible replies on behalf of Shafer-Landau and Railton. However, he does not examine the evolutionary foundations and the related empirical issues on which evolutionary debunking arguments rely.

While Mizzoni's book is refined enough when it deals with the presentation of some the main metaethical and normative theories, philosophers of economics with an interest in evolutionary biology might find problematic that Mizzoni is taking a very narrow approach to evolution in the introduction of the book. There are numerous ways to apply evolutionary theory to investigate ethics and meta-ethics, each of which might provide valuable and novel insights. Revisiting Haught's theistic model of evolution is an interesting addition in terms of completeness and engagement with the arguments discussed in the meta-ethics and normative ethics parts of the book. However, Mizzoni's outline of the four evolutionary models is brief and ignores contemporary evolutionary perspectives on human behaviour. The reader is at a loss to understand why Mizzoni employed sociobiology models originally devised to study animal behaviour while 
contemporary theories that pay specific attention to human evolution are left out.

In the last decades, models that come together under the terms human behavioral ecology (e.g. Nettle et al, 2013), evolutionary psychology (e.g. Cosmides \& Tooby, 2013) and gene-culture co-evolution (e.g. Laland et al, 2015; Henrich, 2015) resulted in exciting breakthroughs in evolutionary thought. Evolutionary psychology focuses on human universals, evolved cognitive mechanisms and the idea of evolutionary mismatch. Gene-culture co-evolution takes up the challenge of analyzing cultural and genetic evolution simultaneously and describes a number of social learning biases that underpin cultural change while human behavioral ecology examines differences in human behaviour as adaptive responses to the environment in which we live. All of them have undoubtedly contributed to the understanding of human behaviour and they could provide the reader with contemporary alternative evolutionary perspectives in the discussion of ethical and meta-ethical issues.

On a more general note, pursuing the ties between economics and metaethics is relatively neglected by philosophers of economics. Mizzoni discusses main issues in metaethics with philosophical sophistication and a wealth of acute insights. His familiarity with the relevant debates and academic literatures is truly impressive. The topics that Mizzoni addresses in the first part of the book and the way in which he frames key problems will appeal to philosophers of economics with a minimal background in evolutionary biology who are looking for a concise introduction to the intricacies of metaethics. In this respect, the book is an excellent introduction to an entire novel cluster of arguments and topics of research.

To conclude, Mizzoni's book is geared to students and early career researchers who might be enticed to consider ethics and meta-ethics as a subject for analysis. The main themes in this book are likely to be relevant to scholars working at the intersection between ethics and evolutionary biology or those who interested in new ways of thinking about the foundations of ethics. For philosophers of economics it may provide useful background knowledge required to follow the recent debates on the complex interplay between evolutionary biology, ethics and economics. Despite its shortcomings, the book is very much worth reading and may satisfy those that are new to the field of ethics and those with a minimal background in evolutionary biology. 


\section{REFERENCES}

Arnhart, Larry. 1998. Darwinian Natural Right: The Biological Ethics of Human Nature. Albany, NY: State University of New York Press.

Axelrod, Robert. 1984. The Evolution of Cooperation. New York: Basic Books.

Binmore, Kenneth. 1994. Game Theory and the Social Contract, vol. I: Playing Fair. Cambridge, MA: MIT Press.

Binmore, Kenneth. 1998. Game Theory and the Social Contract, vol. II: Just Playing. The Cambridge, MA: MIT Press.

Blackburn, Simon. 1996. "I Rather Think I am a Darwinian."Philosophy 71: 605-616.

Boyd, Graig A. 2007. Shared Morality: A Narrative Defence of Natural Law Ethics. Ada, MI: Brazos Press.

Bruni, Luigino, and Robert Sugden. 2013. "Reclaiming Virtue Ethics For Economics.” The Journal of Economic Perspectives 27(4): 141-163.

Broome, John. 1999. Ethics out of Economics. Cambridge: Cambridge University Press.

Cosmides, Leda, and John Tooby. (2013) "Evolutionary Psychology: New Perspectives on Cognition and Motivation." Annual Review of Psychology 64, 201-229.

Churchland, Paul, M. 1996. "The Neural Representation of the Social World." In L. May, M. Friedman, and A. Clark, eds. Mind and Morals: Essays on Ethics and Cognitive Science. Cambridge, MA: MIT Press, 91-108.

Churchland, Paul, M. [1998] 2001. "Toward a Cognitive Neurobiology of the Moral Virtues." In The Foundations of Cognitive Science, ed. Joao Branquinho. New York, NY: Oxford University Press, 77-98.

Henrich, Joseph. 2015. The Secret of Our Success: How Culture is Driving Human Evolution, Domesticating Our Species, and Making Us Smarter. Princeton, NJ: Princeton University Press.

Held, Virginia. 2006. The Ethics of Care: Personal, Political and Global. New York, NY: Oxford University Press,

Hodgson, Geoffrey M. 2013.From Pleasure Machines to Moral Communities: An Evolutionary Economics without Homo Economicus. Chicago, IL: University of Chicago Press.

Laland, Kevin, Matthews, Blake, and Feldman, Marcus W. 2016."An Introduction to Niche Construction Theory." Evolutionary Ecology 30: 191-202

Mizzoni, John. 2005."Darwinian Ethics and Moral Realism.”Biological Theory 9(3):377388

Mizzoni, John. 2010. "Evolution and Error Theory."Social Science Information 49 (2):165-194

Nettle, Daniel, Gibson Mhairi A., David Lawson W., and Rebecca Sear. 2013. "Human behavioral ecology: Current research and future prospects." Behavioral Ecology (24)5: 1031-1040.

Noddings, Nel. 2010. The Maternal Factor: Two Paths to Morality. Berkeley, CA: University of California Press

Nussbaum, Matha. 1988. "Non-Relative Virtues: An Aristotelian Approach." Midwest Studies in Philosophy, XIII: 32-53.

Railton, Peter. 2003. Facts, Values, and Norms: Essays toward a Morality of Consequence. New York, NY: Cambridge University Press.

Ruse, Michael. 1998. Taking Darwin seriously: A Naturalistic Approach to Philosophy. Amherst, MA: Prometheus Books. 
Shafer-Landau, Russ. 2003. Moral Realism: A Defence. New York, NY: Oxford University Press

Singer, Peter. 1981. The Expanding Circle: Ethics and Sociobiology. New York, NY: Farrar, Straus \& Giroux.

Singer, Peter. 1999. A Darwinian Left: Politics, Evolution and Cooperation. New Haven, CT: Yale University Press.

Skyrms, Brian. 1996. Evolution of the Social Contract. Cambridge: Cambridge University Press.

Vromen, Jack. 2017. "Ultimate and Proximate Explanations of Strong Reciprocity." History and Philosophy of the Life Sciences 39(3): 25

de Waal, Frans. 1996. Good Natured: The Origins of Right and Wrong in Humans and other Animals. Cambridge, MA: Harvard University Press.

Wells, Thomas, and Johan Graafland. 2012. "Adam Smith's Bourgeois Virtues in Competition.” Business Ethics Quarterly 22(2): 319-350.

White, Mark D. 2011. Kantian Ethics and Economics: Autonomy, Dignity, and Character Defense of Pluralistic Relativism. Palo Alto, CA: Stanford University Press.

Wong, David B. 2006. Natural Moralities: A Defense of Pluralistic Relativism. New York: Oxford University Press.

Vaios Koliofotis is a $\mathrm{PhD}$ candidate at Erasmus University Rotterdam. His research interests include strategic foundations of human sociality, methodology of evolutionary behavioural economics and ethics as they are applied in engineering. He is an editor of the Erasmus Journal for Philosophy and Economics (EJPE). 